\title{
The Canadian
}

Journal of Linguistics

La Revue canadienne

de Linguistique

Spring/Printemps 1978-23:1

Fall/Automne 1978--23:2 


\section{Canadian Linguistic Association Association canadienne de}

Linguistique

OFFICERS/BUREAU 1978-79

President/Président Normand Beauchemin, Sherbrooke Past President/Président sortant B. Hunter Smeaton, Calgary Vice-President/Vice-Président John Hewson, Memorial Secretary-Treasurer/Secrétaire-Trésorier DAN A. WILson, Queen's

Members of the Executive/Membres du Conseil J. D. Kaye, Montreal G. Prideaux, Alberta Editor/Rédacteur E. N. Burstynsky, Toronto Associate Editor/Rédacteur adjoint P. CARdinal, Ottawa Assistant Editor/Rédacteur assistant J. K. Chambers, Toronto

The canadian journal of linguistics is the official publication of the Association. Annual dues of ten dollars, which include subscriptions to the Journal, are payable to the Treasurer. Available back issues may also be ordered from the Treasurer, Dan A. Wilson, Queen's University, Kingston, Ontario K7L 3N6.

Manuscripts in English or French may be sent to the Editor, Professor J. K. Chambers, Department of Lingustics, University of Toronto, Toronto, Ontario M5S 1A1. A Style Sheet should be secured from the Editor before the final manuscript is typed. Books for review should also be sent to the Editor.

La revue Canadienne de lingustique est l'organe officiel de l'Association canadienne de Lingustique. Le montant de la cotisation, abonnement compris, est de dix dollars et doit être versé au Trésorier. Les manuscrits et toute correspondance relative à la rédaction de la Revue doivent être envoyés au Rédacteur. Les collaborateurs sont prés de demander le protocole de la Revue avant de rédiger la version définitive de leur manuscrit. Les livres pour recensions et les comptes rendus sont à envoyer au Rédacteur.

(C) Canadian Lingustic Association 1980. All rights reserved.

Published by University of Toronto Press.

The canadian journal of linguistics continues the journal of the CANADIAN LINGUISTIC ASSOCIATION.

LA REVUE CANADIENNE DE LINGUISTIQUE fait suite à la REVUE DE L'ASSOCIATION CANADIENNE DE LINGUISTIQUE.

ISSN $0008-4131$ 
THE CANADIAN JOURNAL OF LINGUISTICS

Spring/Printemps 1978-23:1

Fall/Automne 1978-23:2

\section{LA REVUE CANADIENNE DE LINGUISTIQUE}

\section{Contents / Sommaire}

Marie-Paule Ducretet-Bol, Analyse comparative et critique de Togeby et Tesnière 1-54

STANLEY R. MUNRo, Glottochronologic theory: Valid or not in Chinese languages? 55-65

DOUglas c. Walker, Epenthesis in Old French 66-83

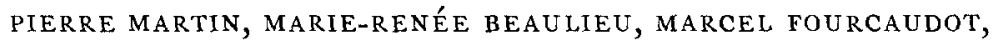
LISE MALO-ELICEIRY, HÉLÈNE TESSIER, La longueur des voyelles en cris $84-106$

margarita suñer, Perception verb complements in Spanish: same or different? $107-27$

Reviews/Comptes rendus

P. G. Patel: garvin (ED.), Cognition: A Multiple View 128-36

Steven n. Dworkin: Hall, Proto-Romance Phonology 136-8

DOUglas C. WALKer: FOLEY, Foundations of Theoretical

Phonology $138-40$

P. LÉON: FRANçOIS, Français parlé 140-4

noel corbett : fleischman, Cultural and Linguistic Factors in Word Formation 144-8

Derorah James: Jacobson, On the Use, Meaning, and Syntax of English Preverbal Adverbs 148-54

THOMAS w. Juntune: fullerton, Historical German Verb Morphology 154-8

albert VALDMAN : ReZeAu, Un patois de Vendée 158-9

E. J. MATTE: ChausÉE, Initiation à la phonétique historique de l'ancien français 160-2 
David huntley: Forsyth, $A$ Grammar of Aspect; Usage and Meaning in the Russian Verb 162-5

H. A. gleason, JR.: ruhlen, $A$ Guide to the Languages of the World 165-70

JOSEPh L. Sub iIONdo: Kempson, Presupposition and the delimitation of semantics $170-4$

lyle campbell: edmonson (ed.), Meaning in the Mayan Languages 174-9

bernard rochet: anderson, Ancient Hispanic Inscriptions $179-80$

henry g. Schogt: Lehrer, Semantic Fields and Lexical Structure 180-3

henRY G. SCHOGT: PALMER, Semantics, a new outline 184-6

DAVID F. ROGERS : CLAPIN, Dictionnaire canadien-fraņ̧ais;

Dionne, Le Parler populaire des canadiens français; Glossaire du parler français au Canada 186-7

James R. Martin: halliday, Learning How to Mean 187-94

c. D. Ellis: wolfart, Meet Cree: A Practical Guide to the Cree Language 194-7

william J. Samarin: Platt \& PLatT, The Social Significance of Speech 197-8

ghyslain charron \& claude germain: brekle, Sémantique 198-200

ghyslain charron \& ClaUde germain: Ledent, Comprendre la sémantique $200-1$ 